
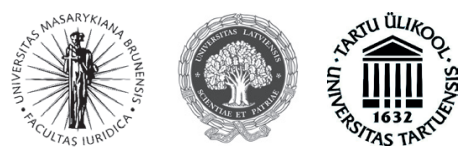

ISSN 1392-6195 (print) ISSN 2029-2058 (online) JURISPRUDENCIJA JURISPRUDENCE 2013, 20(3), p. 923-950.

\title{
THE IMPACT OF GENERAL HUMAN RIGHTS ON THE PROTECTION OF PERSONS BELONGING TO NATIONAL MINORITIES*
}

\author{
Aistė Račkauskaitè-Burneikienè \\ Mykolas Romeris University, Faculty of Law \\ Institute of International and European Union Law \\ Ateities 20, LT-08303 Vilnius, Lithuania \\ Telephone: (+370 5) 2714669 \\ E-mail: aiste.rackauskaite@mruni.eu
}

Received on 19 August, 2013; accepted on 20 September, 2013

doi:10.13165/JUR-13-20-3-05

Abstract. The protection of national minorities forms a constituent part of the international protection of human rights. General human rights treaties (the International Covenant on Civil and Political Rights, the International Covenant on Economic, Social and Cultural Rights, the Convention for the Protection of Human Rights and Fundamental Freedoms and others) create guarantees for the protection of persons belonging to national minorities on the basis of individual human rights. Although the mentioned treaties are not specifically devoted for the protection of national minorities, it is important to underline that non-minorities treaties establish articles of special relevance for persons belonging to national minorities. Non-minorities treaties on the basis of non-discrimination and equality oblige the contracting states to ensure equal treatment of persons, including those belonging to national minorities. It may be noticed that non-minorities treaties provide the protection

The article uses the term "the protection of national minorities" as a synonym for "the protection of persons belonging to national minorities", taking into consideration that both kinds of the mentioned protection create rights for persons belonging to national minorities. 
for persons belonging to national minorities indirectly through the interpretation of the ambit of general human rights. The core question is whether the protection granted on the basis of general human rights is sufficient for the effective protection of persons belonging to national minorities. The aim of the article is to analyze general and specialized international legal grounds of special significance for persons belonging to national minorities in order to determine the particularities of the protection granted for them. The conclusion is drawn that general human rights alone do not effectively protect national minorities: general human rights contribute to the protection of persons belonging to national minorities as a supplement element that inextricably interrelates with specialized rights together comprising the protection devoted to national minorities.

Keywords: international protection of human rights, national minorities, nondiscrimination, equality, rights granted for persons belonging to national minorities, International Covenant on Civil and Political Rights, International Covenant on Economic, Social and Cultural Rights, Convention for the Protection of Human Rights and Fundamental Freedoms, Framework Convention for the Protection of National Minorities.

\section{Introduction}

The international protection of national minorities is an integral part of the international protection of human rights. In another research regarding national minorities, the author stated the following: "The relationships between states were the central object regulated by the classical international law, and the individual in this context was left aside. The protection of human rights, as well as its integral part of the protection of persons belonging to national minorities, was restricted to internal affairs of a state. The two World Wars and their consequences have shown that human rights can not be regulated only under national level. The situation has changed after the World War II when human rights were established in international law. Universally applied international documents establishing the protection of human rights were adopted soon after the World War II and even later, directly or indirectly mentioning the question concerning the protection of persons belonging to national minorities: Universal Declaration of Human Rights, 1948, International Covenant on Civil and Political Rights, 1966, International Covenant on Economic, Social and Cultural Rights, 1966, UN Declaration on Ethnic, Religious and Linguistic Minorities, 1992. The documents of regional application: European Convention on Human Rights and Fundamental Freedoms, 1950, European Charter for Regional, or Minority, Languages, 1992, Framework Convention for the Protection of National Minorities, 1995, - the main international documents for the protection of persons belonging to national minorities, imposing legal obligations for states parties"'.

1 Račkauskaitè-Burneikienė, A. Summary of the Doctoral Dissertation "Linguistic Guarantees for Persons Belonging to National Minorities”. Social Sciences, Law (01 S). Vilnius: Mykolas Romeris University, 2012, p. 259. 
The history of international human rights law confirms that the basic guarantees for the protection of national minorities were formed under principles of non-discrimination and equality. Article 27 of the Covenant on Civil and Political Rights ${ }^{2}$ (hereinafter CCPR) is the unique legally binding provision creating special guarantees for persons belonging to national minorities at universal level. The Framework Convention for the Protection of National Minorities ${ }^{3}$ (hereinafter - Framework Convention) is an international treaty, adopted by the Council of Europe, with the purpose to establish a specialized protection for persons belonging to national minorities. The fundamental question is whether the protection granted on the basis of general human rights can effectively preserve the identity of a national minority or whether it needs a special attention and legal provisions.

International law does not contain any legal definition of a "national minority". However, "the prevailing view is that it is possible to find some elements of the concept of minority endorse by international law and therefore to determine the scope of application of the respective rules ratione personae"4. It is worth to notice that different authors suggest certain definitions of a national minority. Capotorti defines national minority as "a group numerically inferior to the rest part of the population of a State, in a non-dominant position, whose members - being nationals of the State - possess ethnic, religious or linguistic characteristics differing from those of the rest of the population and show, if only implicitly, a sense of solidarity, directed towards preserving their culture, traditions, religion or language". Deschênes describes national minority as "a group of citizens of a State, constituting a numerical minority and in a non-dominant position in that State, endowed with ethnic, religious or linguistic characteristics which differ from those of the majority of the population, having a sense of solidarity with one another, motivated, if only implicitly, by a collective will to survive and whose aim is to achieve equality with the majority in fact and in law". In addition, Girasoli states that identification of minorities is based on the means of "objective indices" (language, ethnic group, religion, culture, number less than half of the population of the state, nondominant position) and "subjective indices" (will to preserve their culture, traditions, religion, language) $)^{7}$. Henrard stresses that "a national or ethnic, religious and linguistic minority is a group numerically smaller that the rest of the population of a state. The members of this non-dominant group have ethnic, religious or linguistic characteristics different form those of the rest of the population and show, even implicitly, a sense of mutual solidarity focused on the preservation of their culture, traditions, religion or

2 International Covenant on Civil and Political Rights. United Nations. Treaty Series. 1966, (999): 171, and (1057): 407.

3 Framework Convention for the Protection of National Minorities. CETS No.: 157.

4 Pantassuglia, G. Minority Issues Handbook. Minorities in International Law. Strasbourg: European Centre for Minority Issues, Council of Europe Publishing, 2007.

5 Henrard, K. Devising an Adequate System of Minority Protection. Individual Human Rights, Minority Rights and the Right to Self-Determination. Hague: Kluwer Law International, 2000, p. 22.

6 Ibid.

7 Girasoli, N. National Minorities: Who Are They? Budapest: Akademia Kiado, 1995, p. 88. 
language" . Although the mentioned definitions are different in their formulations, the same characteristics still remain: numerically smaller group, different language, religion, culture and a will to survive as a group. These features are essential for the identification of a national minority. Thus, it is generally acknowledged ${ }^{9}$ that national minority is as group of persons, numerically smaller than the rest part of a state's population. It is worth to emphasize that national minority is an exclusive group of persons: distinct features (language, culture, ethnic origin, religion) compose particularities that differentiate persons belonging to national minorities from the rest part of a state's population. The conception of national minority contains the objective and subjective criteria that comprise essential characteristics of a national minority. Objective criteria are language, culture, ethnic origin, religion that differ a national minority from the other part of a state's population ${ }^{10}$. Exactly the mentioned objective features create the identity of a national minority. The leading aim of the protection is to preserve the identity of a group of persons, namely, a national minority. Subjective criteria of a national minority are perceived as a common wish to survive as a group and to preserve exclusive and different objective features, namely, language, culture, ethnic origin, religion ${ }^{11}$. The prohibition of discrimination and equality are the main grounds ensuring the protection of general human rights. The equal treatment of persons without any kind of distinction, based on race, colour, sex, language, religion, political or other opinion, national or social origin (that constitute the identity of a national minority) are guaranteed on the grounds of the mentioned principles. The question is whether the general human rights, based on the principles of non-discrimination and equality, can effectively preserve the identity of a national minority. This article seeks to analyze and identify the legal grounds under the international human rights law (the regulation of the European Union do not fall within the scope of the article) for the protection of national minorities. In this context, the article presents the examination of the impact of general human rights on the protection of national minorities. Firstly, the universally and regionally applied provisions of international human rights law as well as the practice of international institutions (the Human Rights Committee, the European Court of Human Rights and others) will be analyzed in order to evaluate the impact and effectiveness of general human rights to preserve the identity of a national minority. Secondly, specialized provisions and documents for the protection of national minorities will be analyzed to clarify the difference of the protection granted on the basis of general human rights and specialized clauses establishing rights for persons belonging to national minorities.

This article presents a comparative research with the dominating methods of systematic analysis method, examining legal provisions, practice of international courts and other institutions (the Human Rights Committee, the Committee of the Elimination of Racial Discrimination).

8 Henrard, K. Devising an Adequate System of Minority Protection. Individual Human Rights, Minority Rights and the Right to Self-Determination. Hague: Kluwer Law International, 2000, p. 55.

9 See the above mentioned definitions.

10 Ibid.

11 Ibid. 


\section{Justification of Minority Rights Under International Human Rights Law}

This section of the article aims to identify certain general and special legal grounds established under international human rights law relevant for the protection of persons belonging to national minorities. The core issue of this section is to analyze the scope and the ambit of the contribution of international human rights law on the purpose to preserve the identity of a national minority. This section focuses on the aim to justify the protection for national minorities on the basis of international human rights law.

\subsection{General Legal Grounds Under International Human Rights Law for the Protection of National Minorities}

\subsubsection{Significant Interpretations of Permanent Court of International Justice}

Starting to analyze the general legal grounds under international human rights law, it is worth to emphasize that Permanent Court of International Justice in its advisory opinion regarding Minority Schools in Albania ${ }^{12}$ has already stated that "the instruments drawn up for the protection of minorities had two main objectives, namely to ensure that individuals belonging to racial, religious or linguistic minorities should be placed on a footing of perfect equality with other nationals of the State, and, secondly, to ensure for the minority element suitable means for the preservation of their racial particularities, their traditions and their national characteristics"13. Thus, the Permanent Court of International Justice acknowledged that the protection of persons belonging to national minorities is justified on the grounds of two elements, first, that requires an equal treatment and, second, that requires a special attention on the purpose to establish, promote and preserve particularities of those persons. The Permanent Court of International Justice emphasized that "these two requirements are indeed closely interlocked, for there would be no true equality between a majority and a minority if the latter were deprived of its own institutions, and were consequently compelled to renounce that which constitutes the very essence of its being as a minority"14. The Permanent Court of International Justice has recognized that the protection of national minorities has to be based on general human rights and special means: general human rights ensure equal treatment with others, while special guarantees contribute as a mean to safeguard the particularities

12 Permanent Court of International Justice. Advisory Opinion of 6 April, 1935. Minority Schools in Albania. Series A./B., No. 64.

13 Capotorti, F. Study on the Rights of Persons Belonging to Ethnic, Religious and Linguistic Minorities. New York: United Nations, 1991, p. 18.

14 Permanent Court of International Justice. Advisory Opinion of 6 April, 1935. Minority Schools in Albania. Series A./B., No. 64, p. 17. 
of a national minority. According to the mentioned statement, it may be concluded that the general protection granted for human rights needs to be supplemented by the special provisions in order to establish and ensure effective protection for persons belonging to national minorities. Particularities that differ persons belonging to national minorities require ensuring the protection of double approach.

After the World War II, the international community has chosen a different approach: the main notion was argued by the idea that principles of non-discrimination and equality are sufficient for the effective protection of persons belonging to national minorities.

\subsubsection{Significant UN Provisions}

Minority rights are human rights. Thus, persons belonging to national minorities are subjects of the protection under international human rights law. The question that rises here is connected with the scope and the ambit of the protection granted under general legal provisions for persons belonging to national minorities, taking into consideration that general human rights clauses do not contain specific notions on national minorities. The principles of non-discrimination and equality reveal the extent of the contribution of general human rights for the protection of national minorities. According to Alfredson, "Equal enjoyment of all human rights and non-discrimination in the application of these rights are established by UN Charter, the Universal Declaration of Human Rights, the International Covenant on Civil and Political Rights, the International Covenant on Economic, Social and Cultural Rights, and a long series of other human rights instruments" 15 .

1.1.2.1. The UN Charter. The UN Charter of 1945 "contains no specific provisions relating to the question of protection of minorities. $<\ldots>$ the Charter of the United Nations solemnly proclaims, in a series of provisions, the principles of universal respect for human rights and fundamental freedoms, equality and non-discrimination"16.

1.1.2.2. The Universal Declaration of Human Rights. In the mentioned Declaration, it is stated that "The international human rights movement was strengthened when the United Nations General Assembly adopted of the Universal Declaration of Human Rights (UDHR) on 10 December 1948. Drafted as 'a common standard of achievement for all peoples and nations', the Declaration for the first time in human history spell out basic civil, political, economic, social and cultural rights that all human beings should enjoy"17. The UDHR proclaimed the principle of non-discrimination: "everyone is entitled to all the rights and freedoms set forth in this Declaration, without distinction of any kind, such as race, colour, sex, language, religion, political or other opinion,

15 Alfredson, G. Minority Rights: A Summary of Existing Practice. In: Phillips, A.; Rosas, A. (eds.). Universal Minority Rights. Turku/Abo, 1995, p. 77-86.

16 Capotorti, F. Study on the Rights of Persons Belonging to Ethnic, Religious and Linguistic Minorities. New York: United Nations, 1991, p. 26-27.

17 United Nation, Human Rights, Charter Based and Treaty Based Bodies, Core International Human Rights Treaties, International Human Rights Law. [interactive]. [accessed on 09-08-2013]. <http://www.ohchr. org/EN/ProfessionalInterest/Pages/InternationalLaw.aspx>. 
national or social origin, property, birth or other status"18 (Art. 2, para. 2). Although the UDHR did not emphasize the particularity of a national minority, "in its resolution 217 C (III) of 10 December 1948, entitled "Fate of Minorities", the General Assembly stated that the United Nations could not remain indifferent to the fate of minorities, but added that it was difficult to adopt a uniform solution of this complex and delicate question, which has special aspects in each State in which it arises"19. Capotorti stated "... that this difficulty was one of the principal reasons for the decision not to mention the problem of minorities in the Universal Declaration of Human Rights" ${ }^{20}$. Despite this fact, national minorities became a subject of the UDHR on the basis of non-discrimination: the prohibited grounds of discrimination (race, colour, language, religion, national origin) relevant in terms of identity entitled national minorities to enjoy rights proclaimed in the UDHR.

\subsubsection{The International Convention on the Elimination of All Forms of Racial} Discrimination (hereinafter - CERD) ${ }^{21}$. The CERD adopted by General Assembly resolution 2106 (XX) of 21 December 1965, determined racial discrimination as meaning "any distinction, exclusion, restriction or preference based on race, colour, descent, or national or ethnic origin which has the purpose or effect of nullifying or impairing the recognition, enjoyment or exercise, on an equal footing, of human rights and fundamental freedoms in the political, economic, social, cultural or any other field of public life" (Art. 1, para. 1). A national minority gained the protection under the CERD on the basis of the objective criteria (race, colour, national or ethnic origin), distinguished in the mentioned definition. The CERD established the legal background for special measures: "special measures taken for the sole purpose of securing adequate advancement of certain racial or ethnic groups or individuals requiring such protection as may be necessary in order to ensure such groups or individuals equal enjoyment or exercise of human rights and fundamental freedoms shall not be deemed racial discrimination, provided, however, that such measures do not, as a consequence, lead to the maintenance of separate rights for different racial groups and that they shall not be continued after the objectives for which they were taken have been achieved" (Art. 1, para. 4). Special measures may be applied to create special guarantees for persons belonging to national minorities and to supplement the general requirement under the CERD. The Committee on the Elimination of Racial Discrimination (hereinafter $-\mathrm{CERD} / \mathrm{C}$ ) in the $32^{\text {nd }}$ General recommendation No. 32 "The Meaning and Scope of Special Measures in the International Convention on the Elimination of All Forms Racial Discrimination" 22 emphasized that equality and

18 Universal Declaration of Human Rights. Adopted by United Nation General Assembly Resolution 217 A (III) of 10 December, 1948.

19 Capotorti, F. Study on the Rights of Persons Belonging to Ethnic, Religious and Linguistic Minorities. New York: United Nations, 1991, p. 27.

20 Ibid.

21 International Convention on the Elimination of All Forms of Racial Discrimination. United Nations. Treaty Series. 1966, (660): 195.

22 The Committee on the Elimination of Racial Discrimination. General Recommendation No. 32 "The Meaning and Scope of Special Measures in the International Convention on the Elimination of All Forms Racial Discrimination“. Distr. GENERAL CERD/C/GC/32, 24 September, 2009. 
non-discrimination are the basis of special measures, which are "designed to secure to disadvantaged groups the full and equal enjoyment of human rights and fundamental freedoms" ${ }^{\prime 2}$. Generally, the CERD distinguished the objective features of a national minority (race, colour, national or ethnic origin) and "acknowledged national minority as a subject which can enjoy special measures"24. Thus, the CERD underlines particular vulnerable groups of persons trough the application of special, although temporary, measures: the application of special measures is limited to the achieved goal. In this way, the CERD manifests the idea of special means in order to maintain a comprehensive protection for the mentioned groups of persons, including national minorities on the basis of objective features. In this context, the CERD is of special relevance for the protection of persons belonging to national minorities.

The CERD/C supervises the implementation of the CERD. Henrard noted that "the supervisory practice of the CERD/C regularly makes statements in this regard which are of specific relevance for minorities. In its concluding observations regarding Denmark for example, it [the CERD/C - added by the author] stated that 'the reported prohibition of the use of the mother tongue in some of these establishments may, though aimed at facilitating integration, lead to indirect discrimination against minorities" ${ }^{25}$; "the CERD/C even explicitly calls on states to ensure that these communities [minority groups - added by the author] can exercise their rights to practice and revitalize their culture and to preserve and to practice their language, that they have adequate levels of political participation (including representation in the police, enforcement agencies), and sometimes also that mother tongue education, bilingual and/or multicultural education (implying adapted textbooks and the like) are guaranteed"26. The mentioned jurisprudence of the CERD/C confirms that the CERD establishes a relevant basis to preserve the identity of a national minority. In this context, it may be concluded that the CERD provides the protection for persons belonging to national minorities on the basis of distinguishing features, which in terms of identity include race, colour, national or ethnic origin. In this way, the CERD determines a legal ground to promote particularities of a national minority.

1.1.2.4. The International Covenant on Civil and Political Rights (hereinafter$C C P R)^{27}$ and the International Covenant on Economic, Social and Cultural Rights

23 The Committee on the Elimination of Racial Discrimination. General Recommendation No. 32 "The Meaning and Scope of Special Measures in the International Convention on the Elimination of All Forms Racial Discrimination“. Distr. GENERAL CERD/C/GC/32, 24 September, 2009, para. 11.

24 Račkauskaitė-Burneikienè, A. Tautinèms mažumoms priklausančiu asmenu kalbinès garantijos: tarptautiniu standartu igyvendinimas Lietuvos Respublikoje. Daktaro disertacija. Socialiniai mokslai, teisè. Vilnius: Mykolo Romerio Universitetas, 2012, p. 33.

25 Henrard, K. The Impact of International Non-discrimination Norms in Combination with General Human Rights for the Protection of National Minorities: Several United Nations Human Rights Conventions. Strasbourg: Committee of Experts on Issues Relating to the Protection of National Minorities, DH$\operatorname{MIN}(2006) 021,24$ October, 2006, p. 7.

26 Ibid., p. 9.

27 International Covenant on Civil and Political Rights. United Nations. Treaty Series. 1966, (999): 171, and (1057): 407. 
(hereinafter-CESCR) ${ }^{28}$. The CCPR of 1966 as well as the CESCR of 1966 established the principle of non-discrimination. The CCPR states that "each State Party to the present Covenant undertakes to respect and to ensure to all individuals within its territory and subject to its jurisdiction the rights recognized in the present Covenant, without distinction of any kind, such as race, colour, sex, language, religion, political or other opinion, national or social origin, property, birth or other status" (Art. 2, para. 1). Accordingly, the CESCR declares that "the States Parties to the present Covenant undertake to guarantee that the rights enunciated in the present Covenant will be exercised without discrimination of any kind as to race, colour, sex, language, religion, political or other opinion, national or social origin, property, birth or other status" (Art. 2, para. 2). Thus, persons belonging to national minorities are subjects, who are able to enjoy human rights granted under the CCPR and the CESCR without any kind of discrimination. Moreover, the CCPR declares the principle of equality: "all persons are equal before the law and are entitled without any discrimination to the equal protection of the law. In this respect, the law shall prohibit any discrimination and guarantee to all persons equal and effective protection against discrimination on any ground such as race, colour, sex, language, religion, political or other opinion, national or social origin, property, birth or other status" (Art. 26). The Human Rights Committee (hereinafter - HRC) in its General Comment No. 18 "Non-discrimination" 29 recognized that Article 2 paragraph 1 is of accessory nature because the application of this notion is limited to rights, established in the CCPR ${ }^{30}$. Article 2 paragraph 2 of the CESCR is of the same accessory origin. On the contrary, Article 26 of the CCPR "does not specify such limitations" 31 . Moreover, the CCPR ensures the protection trough individual human rights (e.g., Art. 17), touching the actual matter for persons belonging to national minorities ${ }^{32}$. Although neither the CCPR nor the CESCR determine the notion of a national minority, persons belonging to national minorities are subjects to claim the guarantees under the CCPR and the CESCR in accordance with the principle of non-discrimination and its accessory nature as well as in accordance with the principle of equality on the grounds of established objective criteria in terms of identity (race, colour, language, religion).

\subsubsection{The Role of the OSCE}

Organization for Security and Cooperation in Europe (hereinafter - OSCE) is a particular organization. According to Bloed, "This is particularly reflected in its strictly political nature in the absence of any constituent treaty, and in its very light institutional

28 International Covenant on Economic, Social and Cultural Rights. United Nations. Treaty Series. 1966, (993): 3.

29 Human Rights Committee. General Comment No. 18 "Non-discrimination". U.N. Doc. HRI/GEN/1/ Rev.1 at 26 (1994), 4 October, 1990.

30 Ibid., para. 12.

31 Ibid.

32 Diergaardt et al. v. Namibia, No. 760/1997, UN Doc. CCPR/C/69/D/760/1997; Coeriel and UArik v. Netherlands, No. 453/1991, UN Doc. CCPR/C/52/D/453/1991. 
structure"33. The documents adopted in the area of the OSCE activities do not define a national minority, although Helsinki Final Act of 1975 already recognized that "the participating States on whose territory national minorities exist will respect the right of persons belonging to such minorities to equality before the law, will afford them the full opportunity for the actual enjoyment of human rights and fundamental freedoms and will, in this manner, protect their legitimate interests in this sphere" 34 . Although later adopted documents ${ }^{35}$ declared the problem of national minorities, they were not of particular significance for the protection of national minorities. Bloed also stated that "the strictly political nature of this scrutiny/supervision/monitoring task of the OSCE results in a perfect complementarity with the Council of Europe with its more (quasi-) legal systems of monitoring human rights implementation" 36 . Because of this reason, the OSCE activities and documents do not fall deeper into the ambit of the article.

\subsubsection{Significance of the Convention for the Protection of Human Rights and Fundamental Freedoms}

The Convention for the Protection of Human Rights and Fundamental Freedoms (hereinafter - ECHR) does not contain special provisions for the protection of national minorities. Only Article 14 contains a notion of non-discrimination: "the enjoyment of the rights and freedoms set forth in this Convention shall be secured without discrimination on any ground such as sex, race, colour, language, religion, political or other opinion, national or social origin, association with a national minority, property, birth or other status" "37. Article 14 distinguishes prohibited grounds of discrimination. It is worth to mention that one of the prohibited grounds of discrimination is "association with a national minority". The identical prohibited grounds of discrimination are also established in Article 1 paragraph 1 of Protocol No. $12^{38}$. This is particularly important in the context of the consideration about the extent, to which general human rights can contribute to the protection of national minorities. The background for this consideration is provided on the basis of the mentioned Article 14 and Protocol No. 12 to the ECHR. These prohibited grounds of discrimination determined in Article 14 and Article 1 paragraph 1 of Protocol No. 12 form a legal basis to extend the scope of general human

33 Bloed, A. Monitoring the Human Dimension of the OSCE. In: Alfredson, G.; Grimheden, J.; Ramcharan, B. G.; de Zayas, A. (eds.). International Human Rights Monitoring Mechanisms. Essays in Honour of Jakob Th. Moller. Hague: Kluwer Law International, 2001, p. 633.

34 Helsinki Final Act. [interactive]. [accessed on 12-09-2013]. <http://www.osce.org/mc/39501? download=true $>$.

35 Concluding Document of the Madrid Meeting of 1983, Concluding Document of the Vienna Meeting of 1989.

36 Bloed, A. Monitoring the Human Dimension of the OSCE. In: Alfredson, G.; Grimheden, J.; Ramcharan, B. G.; de Zayas, A. (eds.). International Human Rights Monitoring Mechanisms. Essays in Honour of Jakob Th. Moller. Hague: Kluwer Law International, 2001, p. 639.

37 Convention for the Protection of Human Rights and Fundamental Freedoms. CETS No.: 005.

38 Protocol No. 12 to the Convention for the Protection of Human Rights and Fundamental Freedoms. CETS No.: 177. 
rights to questions relating to particularities of a national minority. This statement can be argued on the basis of the jurisprudence of the European Court of Human Rights (hereinafter - the Court).

It is important to underline that the application of the ECHR extends to everyone within the jurisdiction of a contracting party, as it is stated in Article 1 of the ECHR. The content of Article 1 in conjunction with Article 14 and Article 1 paragraph 1 of Protocol 12 theoretically provides the idea to interpret those clauses as ensuring specific rights for national minorities. However, the ECHR is more likely to protect rights of persons belonging to national minorities through general human rights rather than to establish special guarantees for those persons. The Court holds the view that the ECHR does not contain specific protection for national minorities: "Neither of these articles is designed to create specific rights for national minorities. <..> Article 14 provides for the prohibition of discrimination in the exercise of the individual rights set forth in the Convention while Article 1 of Protocol No. 12 provides for a general prohibition of discrimination in the exercise of the individual rights set forth by the national law of the States parties to the Convention"39. According to Tulkens, "an examination of the Court's case-law shows that the rights of national or other minorities are protected in particular by Articles 9 (freedom of thought, conscience and religion), 10 (freedom of expression) and 11 (freedom of association) of the Convention and Article 3 of Protocol no. 1 (right to free elections). These rights are central to all problems concerning minorities, as religion, language and traditions are all fundamental aspects of identity, and the possibility to exercise these rights in public or private, individually or collectively, is the means by which this identity can be acknowledged, transmitted and preserved" 40 . Moreover, the Court acknowledges that the protection for national minorities is a "condition sine qua non for a democratic society" 41 . The Court underlines that "referring to the hallmarks of a 'democratic society', the Court has attached particular importance to pluralism, tolerance and broadmindedness. In that context, it has held that although individual interests must on occasion be subordinated to those of a group, democracy does not simply mean that the views of the majority must always prevail: a balance must be achieved which ensures the fair and proper treatment of minorities and avoids any abuse of a dominant position" 42 . In this context, it may be concluded that the margin of appreciation that contracting states have under the ECHR is restricted on the basis of "democratic society" with the purpose to ensure the mentioned "balance" and "proper treatment of minorities". This may lead to the conclusion that rights of persons belonging to national minorities are not directly established under the ECHR, but the protection of those persons are grounded on the aims of democratic society in the context of the ECHR.

39 Tulkens, F. The Protection of National Minorities in the Case-Law of the European Court of Human Rights. Strasbourg: Committee of Experts on Issues Relating to the Protection of National Minorities (DH-MIN), 7th Meeting, 12-13 March, 2008, p. 2, para. 2.

$40 \quad$ Ibid., p. 7, para. 16.

41 Gorzelick and Others v. Poland, [GC], No. 44158/98, 17 February, 2004, ECHR 2004-I, para. 68.

42 Baczkowski and Others v. Poland, No. 1543/06, 3 May, 2007, para. 63. 
Moreover, it may be added that the protection granted for persons belonging national minorities under the ECHR is indirect: the ECHR is not considered as a specialized document for the protection of persons belonging to national minorities. Still, the Court's case-law confirms that rights of persons belonging to national minorities generate and derive from human rights, e.g., the Court acknowledges that disputes concerning names and forenames of natural persons fall within the scope of Article 8 of the ECHR ${ }^{43}$. Although rights granted for persons belonging to national minorities originate from general human rights, the protection, granted under the ECHR, is not sufficient with the purpose to preserve the identity of a national minority, e.g., the right to use name and surname falls within the scope of Article 8 of the ECHR. However, the Court recognizes only the aspect of family and private life. Accordingly, the preservation of the identity of a national minority is left aside: "the Court notes that Article 8 (art. 8) does not contain any explicit reference to names. Nonetheless, since it constitutes a means of personal identification and a link to a family, an individual's name does concern his or her private and family life" ${ }^{44}$. The Court's case-law does not confirm that the ECHR protects spelling in the minority language ${ }^{45}$. In this context, it may be concluded that the ECHR does not specifically protect persons belonging to national minorities. Thus, general human rights can not effectively and fully protect the identity of a national minority.

It is worth to pay attention to the fact that the protection granted under the ECHR is limited to the ambit of Article 14 of the ECHR, as well as Article 2 paragraph 1 of the CCPR, and Article 2 paragraph 2 of the CESCR is not autonomous. Therefore, Article 14 of the ECHR does not prohibit discrimination outside the scope of the ECHR. The European Court of Human Rights in many cases has confirmed the limited ambit of Article 14 and its non-autonomous nature: "it is true that this guarantee has no independent existence in the sense that under the terms of Article 14 (art. 14) it relates solely to "rights and freedoms set forth in the Convention"" 46 ; "Article $14<\ldots>$ constitutes one particular element (non-discrimination) of each of the rights safeguarded by the Convention. $<\ldots>$ The Articles enshrining those rights may be violated alone and/or in conjunction with Article 14 (art. 14)" ${ }^{47}$. Moreover, the application of Article 14 of the ECHR is restricted to "a clear inequality of treatment in the enjoyment of the right in question" 48 , which

43 See the judgments of European Court of Human Rights in Burghartz v. Switzerland, 22 February, 1994, Series A No. 280 B, p. 28, section 24; Stjerna v. Finland, 25 November, 1994, Series A No. 299 B, p. 60, section 37; Guillot v. France, 24 October, 1996, Reports 1996 V, p. 1602-1603, section 21; Šiskina and Šiškins v. Latvia (dec.), No. 59727/00, 8 November, 2001; decision on admissibility Application No. $71074 / 01$ by Juta MENTZEN also known as MENCENA against Latvia.

44 Burghartz v. Switzerland, No. 16213/90, 22 February, 1994, Series A No. 280-B, para. 24; Stjerna v. Finland, No. 18131/91, 25 November, 1994, Series A No. 299-B, para. 37.

45 Mentzen v. Latvia (dec.), No. 71074/01, 7 December, 2004, ECHR 2004-XII; Kemal Tažkżn and Others v. Turkey, No. 30206/04, 37038/04, 43681/04, 45376/04; Güzel Erdagöz v. Turkey, No. 37483/02, 21 October, 2008, 12881/05, 28697/05, 32797/05 and 45609/05, 2 February, 2010. 
"is a fundamental aspect of the case" 49 . In this context, it can be agreed with Tulkens, who notes that "the Convention does not provide for any specific collective rights for minorities. From the material standpoint $(\boldsymbol{A})$, this protection is only an indirect form of protection, via the individual rights of persons belonging to a minority. From the personal standpoint $(\boldsymbol{B})$, it does not apply only to the members of minorities residing on the territory of States parties to the Convention but also to foreigners coming under the jurisdiction of a State party to the Convention and belonging to a minority residing in a third country" 50 . Henrard underlines that "the prohibition of non-discrimination in its restricted version does not guarantee the achievement of substantive equality, which is essential for members of minorities. Consequently, the avenue of individual human rights and the prohibition of discrimination give little support to the minorities crucial right to identity" 51 . This leads to the conclusion that the protection of persons belonging to national minorities flowing from the ECHR is quite theoretical: the ECHR does not establish specific provisions for national minorities. For this reason, the Court is not obliged to protect national minorities, according to the text of the ECHR ${ }^{52}$. Thus, general human rights cannot offer the sufficient protection for national minorities.

The ECHR "does not contain specific minority rights provisions and from that perspective, it can only deal with the concerns of minorities in an indirect way" 53 . The indirect way of the ECHR derives from the protection based on individual human rights $^{54}$ : although rights essential for national minorities is guaranteed in the limited area, national minorities can be protected under the ECHR via individual human rights. In this way, a will to survive as a group and the enjoyment of collective rights are not granted under the ECHR.

To conclude, the principles of non-discrimination and equality form the core grounds for the international protection of human rights. The rights of persons belonging to national minorities can be interpreted as originating from general human rights. Therefore, the rights of persons belonging to national minorities can fall within the scope of general human rights. However, the protection deriving from general human rights is restricted to the content of a certain human right (as mentioned before, names and surnames of natural persons relate to a general human right to respect family and

49 Airey v. Ireland, No. 6289/739, October 1979, Series A No. 32, para 30.

50 Tulkens, F. The Protection of National Minorities in the Case-Law of the European Court of Human Rights. Strasbourg: Committee of Experts on Issues Relating to the Protection of National Minorities (DH-MIN), 7th Meeting, 12-13 March, 2008, p. 6.

51 Henrard, K. Devising an Adequate System of Minority Protection. Individual Human Rights, Minority Rights and the Right to Self-Determination. Hague: Kluwer Law International, 2000, p. 142.

52 Decision on admissibility Application No. 71074/01 by Juta MENTZEN also known as MENCENA against Latvia.

53 European Commission for Democracy through Law. Report on Non-citizens and Minority Rights. Venice, 15-16 December, 2006. Council of Europe, No. CDLAD(2007)001 Or. Engl., p. 5.

54 Stjerna v. Finland, 25 November, 1994, No. 18131/91, 25 November, 1994, Application No. 18131/91, Series A No. 299-B; Informationsverein Lentia and Others v. Austria, 24 November, 1993, Application No. 13914/88; 15041/89; 15717/89; 15779/89; 17207/90; Case "Relating to Certain Aspects of the Laws on the Use of Languages in Education in Belgium” v. Belgium (merits), No. 1474/62, 23 July, 1968, Series A No. 6. 
private life, however, this general human right does not contain specific spelling in the minority language, what is crucial for the identity of a national minority). This leads to the conclusion that general human rights per se do not establish rights for persons belonging to national minority and constitute an indirect mechanism for their protection. This indirect mechanism needs to be supplemented by provisions and documents (which are analyzed further), establishing the specialized protection for persons belonging to national minorities. In conclusion, the mentioned indirect mechanism is not sufficient for the effective protection of national minorities.

\section{Special Guarantees for National Minorities}

This section of the article concentrates on specialized documents and legal clauses devoted for the protection of national minorities. Thus, this section of the article seeks to demonstrate that general human rights do not ensure the effective protection for national minorities without supplementary special guarantees.

\subsection{Relevant UN Documents}

2.1.1. The Significance of the CCPR. The CCPR established a universally applied provision, especially relevant for the protection of national minorities. Article 27 of the CCPR contains a special clause: "in those States in which ethnic, religious or linguistic minorities exist, persons belonging to such minorities shall not be denied the right, in community with the other members of their group, to enjoy their own culture, to profess and practise their own religion, or to use their own language". Article 27 of the CCPR is the only legal clause of the universal application that indicates particularities of a national minority on the basis of ethnic, religion, language and culture. Article 27 of the CCPR is recognized as being the first legally binding clause of the universal application ensuring rights for persons belonging to national minorities.

Although Article 27 of the CCPR do not explicitly indicate the definition of a national minority, this article singles out the features of a national minority (ethnic origin, religion, language, culture) that create a legal ground to protect national minorities under these grounds. Thus, persons belonging to national minorities fall within the scope of Article 27 of the CCPR. The HRC in its "General Comment No. 23: The Rights of Minorities (Art. 27)" explained the content of Article 27 of the CCPR and emphasized that "the terms used in article 27 indicate that the persons designed to be protected are those who belong to a group and who share in common a culture, a religion and/or a language". It is especially important to underline that in the General Comment No. 23 the HRC presented the conception of a national minority in a very broad sense: "Article 27 confers rights on persons belonging to minorities which "exist" in a State party. Given the nature and scope of the rights envisaged under that article, it is not relevant

55 Human Rights Committee. General Comment No. 23: The Rights of Minorities (Art. 27). 8 April, 1994, CPR/C/21/Rev.1/Add.5. 
to determine the degree of permanence that the term "exist" connotes. Those rights simply are that individuals belonging to those minorities should not be denied the right, in community with members of their group, to enjoy their own culture, to practise their religion and speak their language. Just as they need not be nationals or citizens, they need not be permanent residents. Thus, migrant workers or even visitors in a State party constituting such minorities are entitled not to be denied the exercise of those rights. As any other individual in the territory of the State party, they would, also for this purpose, have the general rights, for example, to freedom of association, of assembly, and of expression. The existence of an ethnic, religious or linguistic minority in a given State party does not depend upon a decision by that State party but requires to be established by objective criteria". In this way, the HRC has recognized a broad scope of Article 27 in terms of ratione personae: the HRC acknowledged that Article 27 of the CCPR provides guarantees for nationals, permanent residents and even migrant workers as well as visitors of a state.

In the supervisory jurisprudence, the HRC elaborates on the concept of a national minority: "as to article 27, the Committee observes that this provision refers to minorities in States; this refers, as do all references to the "State" or to "States" in the provisions of the Covenant, to ratifying States. Further, article 50 of the Covenant provides that its provisions extend to all parts of Federal States without any limitations or exceptions. Accordingly, the minorities referred to in article 27 are minorities within such a State, and not minorities within any province. A group may constitute a majority in a province but still be a minority in a State and thus be entitled to the benefits of article 27'. According to the HRC case-law, only the group that forms a minority within a state has a right to claim guarantees under Article 27 of the CCPR.

It is important to emphasize that the HRC holds the view that the way of life (living in the reserves ${ }^{56}$, reindeer breeding ${ }^{57}$ ) is protected under Article 27 of the CCPR trough the protection of individual human rights, because Article 27 of the CCPR do not guarantee collective rights. It follows that Article 27 of the CCPR broadly protects persons belonging to national minorities through the individual human rights, although the protection of collectivity is not introduced: "The Committee observes that this article establishes and recognizes a right which is conferred on individuals belonging to minority groups and which is distinct from, and additional to, all the other rights which, as individuals in common with everyone else, they are already entitled to enjoy under the Covenant" 58 . Akermark stresses that "Article 27 of the CCPR refers to "persons belonging to minorities". The fact that Article 27 is placed in the context of a document on individual civil and political rights (with the exception of Article 1 on selfdetermination of peoples), that the travaux preparatoires to the Covenant emphasize that minorities do not have a legal personality in international law, and the fact that Optional

56 Sandra Lovelace v. Canada, No. 24/1977, 30 July, 1981, U.N. Doc. Supp. No. 40 (A/36/40).

57 Ivan Kitok v. Sweden, No. 197/1985, 27 July, 1988, U.N. Doc. CCPR/C/33/D/197/1985.

58 Human Rights Committee. General Comment No. 23: The Rights of Minorities (Art. 27). 8 April, 1994, CPR/C/21/Rev.1/Add.5, para. 1. 
Protocol to the Covenant recognizes locus standi only to individuals, are all arguments supporting the position that Article 27 guarantees only individual rights".

It may be underlined that the central goal of the international protection of human rights is to ensure general human rights in conjunction with non-discrimination and equality, which create only basic guarantees for the protection of persons belonging to national minorities without a special purpose to preserve the particularities of a national minority. In this context, it is important to notice that principles of non-discrimination and equality in combination with general human rights protect persons belonging to national minorities in a narrow sense on the basis of individual human rights. It is worth to add that the protection of this nature is restricted to the scope of a certain general human right or even to the application of non-autonomous principal of nondiscrimination. Thus, supervisory bodies (HRC, CERD or other) or European Court of Human Rights are free to conclude that specific questions regarding persons belonging to national minorities do not fall within the ambit of a certain general human right. Thus, the effective protection of persons belonging to national minorities needs special guarantees that are not provided by general human rights. The analysis of the general legal provisions has revealed that international human rights law grants the protection for persons belonging to national minorities indirectly on the basis of non-discrimination and equality in combination with general human rights. The mentioned grounds are effectively applied as ensuring general human rights for all persons, including those belonging to national minorities. However, the examination of general legal clauses has confirmed that general human rights do not per se preserve the particularities of a national minority.

Article 27 of the CCPR was the first international legal clause, which significantly granted protection for persons belonging to national minorities, although the CPPR is not considered as a specialized international treaty devoted for the protection of national minorities. Generally, it may be concluded that international human rights law has recognized the importance and the need for specialized legal clauses regarding national minorities in a progressive manner: firstly, the priority was given to general human rights and only later the protection for national minorities was broaden on the basis of specialized legal clauses and even certain international treaties.

2.1.2. The Significance of the Declaration on the Rights of Persons Belonging to National or Ethnic, Religious and Linguistic Minorities. The Declaration on the Rights of Persons Belonging to National or Ethnic, Religious and Linguistic Minorities of 18 December, 1992 is the first UN document in corpre detailing rights of persons belonging to national minorities.

Article 27 of the CCPR was the first legally binding provision of the universal nature included in the CCPR - international treaty for the protection of general human rights. Thus, the Declaration is often named as a continuation of Article 27 of the $\mathrm{CCPR}^{59}$. A distinctive feature of the Declaration is that this document specifically deals with the rights of persons belonging to national minorities, i.e., the Declaration notes

59 Kovaševič, D. International Minority Protection System. [interactive]. [accessed on 14-10-2010]. <http:// www.kas.de/upload/auslandshomepages/serbien/Kovacevic_en.pdf $>$. 
that national minorities need to be protected not only in the narrow sense of individual human rights, but the special guarantees should be applied in order for national minority to survive as a group. Although the Declaration does not define a national minority, "the UN Declaration on Minorities should only be seen as a stepping stone in the forward movement of minority rights". ${ }^{60}$ In this context, it may be said that a national minority under the Declaration is identified on the same basis of race, language, culture, religion and ethnicity.

The Declaration acknowledges not only traditionally recognized rights granted for persons belonging to national minorities (the right to use language, practice religion, enjoy culture), but also modern rights: "the right to participate effectively in cultural, religious, social, economic and public life" (Art. 2, para. 2), "the right to participate effectively in decisions on the national and, where appropriate, regional level concerning the minority to which they belong or the regions in which they live, in a manner not incompatible with national legislation" (Art. 2, para. 3), "the right to establish and maintain their own associations" (Art. 2, para. 4). In general, the Declaration underlines national minority as a group of persons with special needs, which have to be protected under general human rights clauses ("States shall take measures where required to ensure that persons belonging to minorities may exercise fully and effectively all their human rights and fundamental freedoms without any discrimination and in full equality before the law" (Art. 4, para.1) in conjunction with special guarantees (before mentioned Art. 2, para. 2; Art. 2, para. 3; Art. 2, para. 4). The Declaration, although not legally binding, presents the approach of international community to pay specific attention to national minorities at international level, thus, the Declaration recognizes a preferential treatment: "the purpose of such preferential treatment is to achieve equal enjoyment of all human rights. The Declaration on Minorities dies provide for special measures, mainly in operative Article 4 and also in other places, but these provisions are less extensive and less forthright than the accumulation of standards set forth in previously existing instruments" ${ }^{\prime \prime}$.

2.2. Significant Documents Adopted by the Council of Europe. The Council of Europe has adopted the most relevant documents in the area of specialized documents for the protection of persons belonging to national minorities: European Charter for Regional or Minority Languages ${ }^{62}$ (hereinafter - Charter) and Framework Convention for the Protection of National Minorities ${ }^{63}$ (hereinafter - Framework Convention).

As the Explanatory Report of the Charter confirms, "it is designed to protect and promote regional or minority languages as a threatened aspect of Europe's cultural heritage. For this reason it not only contains a non-discrimination clause concerning the use of these languages but also provides for measures offering active support for them: the aim is to ensure, as far as reasonably possible, the use of regional or minority languages

60 Alfredson, G. Minority Rights: A Summary of Existing Practice. In: Phillips, A.; Rosas, A. (eds.). Universal Minority Rights. Turku/Abo, 1995, p. 77-86.

61 Ibid.

62 European Charter for Regional or Minority Languages. CETS No.: 148.

63 Framework Convention for the Protection of National Minorities. CETS No.: 157. 
in education and the media and to permit their use in judicial and administrative settings, economic and social life and cultural activities. Only in this way can such languages be compensated, where necessary, for unfavourable conditions in the past and preserved and developed as a living facet of Europe's cultural identity" ${ }^{\prime 6}$. Generally, the Charter is relevant for the preservation of the linguistic identity of a national minority: "the charter sets out to protect and promote regional or minority languages, not linguistic [emphasis added] minorities. For this reason emphasis is placed on the cultural dimension and the use of a regional or minority language in all the aspects of the life of its speakers. The charter does not establish any individual or collective rights for the speakers of regional or minority languages" ${ }^{65}$. As Henrard notes, the Charter "confirms furthermore the possible importance of measures promoting multiculturalism, including multilingualism, for the protection of minorities. This acknowledgement can arguably be related to the attitude $<\ldots>$ regarding minority protection in a plural society, since that would amount to a search for the best possible accommodation of the population diversity in a state" ${ }^{96}$.

The Framework Convention is a particularly important and unique international treaty for the protection of persons belonging to national minorities: this Convention is "the first comprehensive treaty addressing minority rights" ${ }^{67}$. As the Explanatory Report of the Framework Convention states, this Convention "is the first legally binding multilateral instrument devoted to the protection of national minorities in general. Its aim is to specify the legal principles which States undertake to respect in order to ensure the protection of national minorities" $" 68$.

Although the Council of Europe tried to find a common view to national minorities as well as a common definition by the resolutions and suggestions to adopt an additional protocol to the ECHR concerning the protection of national minorities ${ }^{69}$, the most significant role in the frame of the concept of a national minority and in the frame of the protection of national minorities is played by the Framework Convention for the Protection of National Minorities: "The Framework Convention for the Protection of National Minorities (Framework Convention) is the most comprehensive of the Council of Europe instruments touching on minority rights" ${ }^{\prime 70}$. The Framework Convention does not establish a definition of a national minority. Explanatory Report of the Framework Convention explains that "it was decided to adopt a pragmatic approach, based on the recognition that at this stage, it is impossible to arrive at a definition capable of mustering

64 Explanatory Report of European Charter for Regional or Minority Languages, ETS No. 148, para. 10.

65 Ibid., para. 11.

66 Henrard, K. Devising an Adequate System of Minority Protection. Individual Human Rights, Minority Rights and the Right to Self-Determination. Hague: Kluwer Law International, 2000, p. 216-217.

67 Weller, M. The Rights of Minorities. A Commentary on the European Convention for the Protection of National Minorities. Oxford: Oxford University Press, 2005. Preface.

68 Explanatory Report of the Framework Convention for the Protection of National Minorities, ETS No. 157, para. 10.

69 See Parliamentary Assembly. Recommendation No. 1134 (1990), Recommendation No. 1201 (1993), Recommendation No. 1492 (2001).

70 Thornberry, P. The Framework Convention on National Minorities: A Provisional Appraisal and Memory of the Baltic States. Baltic Yearbook of International Law. 2002, 2: 127-157. 
general support of all Council of Europe member States"71. Thus, contracting parties have to determine the application of the Framework Convention for persons ${ }^{72}$. Some contracting parties determined the application of the Framework Convention for persons by declarations ${ }^{73}$, other contracting parties - in the reports on the implementation of the Framework Convention ${ }^{74}$.

Although contracting parties have a margin of appreciation to determine personal scope of the Framework Convention, the Advisory Committee stresses that "the implementation of the Framework Convention should not be a source of arbitrary or unjustified distinctions"75. According to the Advisory Committee, "for this reason, the Advisory Committee considers that it is part of its duty to examine the personal scope given to the implementation of the Framework Convention in order to verify that no arbitrary or unjustified distinctions have been made"76. Thus, the Advisory Committee on

71 Explanatory Report of the Framework Convention for the Protection of National Minorities, para. 12. [interactive]. [accessed on dd-mm-yyyy]. <http://www.coe.int/t/dghl/monitoring/minorities/1_AtGlance/ PDF_H(95)10_FCNM_ExplanReport_en.pdf $>$.

72 Advisory Committee: Opinion on Armenia, 16 May, 2002, ACFC/INF/OP/I(2003)001, para. 14; Opinion on Albania, 12 September, 2002, ACFC/INF/OP/I(2003)004, para. 17; Opinion on Austria, 16 May, 2002, ACFC/INC/OP/I(2002)009, para. 13; Opinion on Bosnia and Herzegovina, 27 May, 2004, ACFC/INF/ OP/I(2005)003, para. 20; Opinion on Bulgaria, 27 May, 2004, ACFC/OP/I(2006)001, para. 13; Opinion on Croatia, 6 April, 2001, ACFC/INF/OP/I(2002)003, para. 14; Opinion on Cyprus, 6 April, 2001, ACFC/INF/OP/I(2002)004, para. 14; Opinion on Czech Republic, 6 April, 2001, ACFC/INF/I(2002)002, para. 13; Opinion on Denmark, 22 September, 2000, ACFC/INF/OP/I(2001)005, para. 13; Opinion on Estonia, 14 September, 2001, ACFC/INF/OP/I/(2002)005, para. 14; Opinion on Georgia, 19 March, 2009 , ACFC/OP/I(2009)001, para. 22; Opinion on Hungary, 22 September, 2000, ACFC/INF/OP/I(2001)004, para. 11; Opinion on Ireland, 22 May, 2003, ACFC/INF/OP/I(2004)003, para. 19; Opinion on Latvia, 9 October, 2008, ACFC/OP/I(2008)002, para. 15; Opinion on Lithuania, 21 February, 2003, ACFC/INF/ OP/I(2003)008, para. 15; Opinion on Malta, 31 November, 2000, ACFC/INFOP/I(2001)006, para. 10; Opinion on Montenegro, 28 February, 2008, ACFC/OP/I(2008)001, para. 21; Opinion on the Netherlands, 25 June, 2009, ACFC/OP/I(2009)002, para. 17; Opinion on Norway, 12 September, 2002, ACFC/INF/ OP/I(2003)003, para. 16; Opinion on Poland, 27 November, 2003, ACFC/INF/OP/I(2004)005, para. 16; Opinion on Portugal, 16 October, 2006, ACFC/OP/I(2006)002, para. 14.

73 Council of Europe Treaty Office. [interactive]. [accessed on 03-09-2013]. <http://www.conventions.coe. int/Treaty/Commun/ListeDeclarations.asp?NT=157\&CM=8\&DF=04/03/2012\&CL=ENG\&VL=1>.

74 Report submitted by Armenia pursuant to Article 25, paragraph 1 of the Framework Convention for the Protection of National Minorities, 11 June, 2001, ACFC/SR(2001)004, para. 36; Report submitted by Hungary pursuant to Article 25, paragraph 1 of the Framework Convention for the Protection of National Minorities, 21 May, 1999, ACFC/SR/(1999)010, para. 24; Report submitted by Slovakia pursuant to Article 25, paragraph 1 of the Framework Convention for the Protection of National Minorities, 4 May, 1999, ACFC/SR(1999)008, para. 7-8.

75 Advisory Committee: Opinion on Austria, 16 May, 2002, ACFC/INF/OP/I(2002)009, para. 14; Opinion on Ukraine, 1 March, 2002, ACFC/INF/OP/I(2002)010, para. 14.

76 Advisory Committee: Opinion on Armenia, 12 May, 2002, ACFC/INF/OP/I(2003)001, para. 16; Opinion on Albania, 12 October, 2002, ACFC/INF/OP/I(2003)004, para. 19; Opinion on Azerbaijan, 22 May, 2003, ACFC/INF/OP/I(2004)001, para. 19; Opinion on Bosnia and Herzegovina, 27 May, 2004, ACFC/ INF/OP/I(2005)003, para. 22; Opinion on Bulgaria, 27 May, 2004, ACFC/INF/OP/I(2006)001, para. 15; Opinion on Croatia, 6 April, 2001, ACFC/INF/OP/I(2002)003, para. 16; Opinion on Cyprus, 6 April, 2001, ACFC/INF/OP/I(2002)004, para. 16; Opinion on Czech Republic, 6 April, 2001, ACFC/INF/ OP/I(2002)002, para. 15; Opinion on Denmark, 22 September, 2000, ACFC/INF/OP/I(2001)005, para. 15; Opinion on Finland, 22 September, 2000, ACFC/INF/OP/I(2001)002, para. 13; Opinion on Georgia, 19 March, 2009, CFC/OP/I(2009)001, para. 24; Opinion on Hungary, 22 September, 2000, ACFC/ INF/ 
the basis of article by article approach seeks to extend the application of the Framework Convention even for those persons that are not recognized by a certain contracting party as a national minority ${ }^{77}$.

The Framework Convention recognizes the interaction between general individual human rights and rights granted for persons belonging to national minorities: Article 1 of the Framework Convention stipulates that "the protection of national minorities and of the rights and freedoms of persons belonging to those minorities forms an integral part of the international protection of human rights, and as such falls within the scope of international co-operation". The Framework Convention establishes specific rights for persons belonging to national minorities, such as "the right to freedom of expression of every person belonging to a national minority" that "includes freedom to hold opinions and to receive and impart information and ideas in the minority language, without interference by public authorities and regardless of frontiers" (Art. 9, para. 1), "the right to use freely and without interference his or her minority language, in private and in public, orally and in writing" (Art. 10, para. 1), the rights "to use the minority language in relations between those persons and the administrative authorities" (Art. 10, para. 2), "the right to use his or her surname (patronym) and first names in the minority language and the right to official recognition of them" (Art. 11, para. 1), "the right to learn his or her minority language" (Art. 14, para. 1). Although some rights established in the Framework Convention are of non-self-executing nature and are restricted on the basis of "areas traditionally inhabited by substantial numbers of persons belonging to a national minority" (Art. 11, para. 3) or "areas inhabited by persons belonging to national minorities traditionally or in substantial numbers" (Art. 14, para. 2), the Framework Convention "is clearly a result of the impressive renaissance of international efforts to safeguard the rights of persons belonging to national minorities"78. The content of the mentioned clauses confirm that the Framework Convention covers specific rights for persons belonging to national minorities that do not fall within the scope of general human rights. Henrard emphasizes that the Framework Convention "in certain respects

OP/I(2001)004, para. 13; Opinion on Ireland, 22 May, 2003, ACFC/INF/OP/I(2004)003, para. 21; Opinion on Latvia, 3 October, 2008, ACFC/OP/I/(2008)002, para. 17; Opinion on Lithuania, 21 February, 2003, $\mathrm{ACFC} / \mathrm{INF} /(\mathrm{OP} / \mathrm{I}(2003) 008$, para. 17; Opinion on Malta, 30 November, 2000, ACFC/INF/OP/I(2001)006, para. 12; Opinion on Moldova, 1 March, 2002, ACFC/INF/OP/I(2003)002, para. 19; Opinion on Norway, 12 September, 2002, ACFC/INF/ OP/OP/I(2003)003, para. 18; Opinion on Portugal, 6 October, 2006, ACFC/OP/I(2006)002, para. 16; Opinion on Russian Federation, 13 September, 2002, ACFC/INF/ OP/I(2003)005, para. 19; Opinion on Serbia, 27 November, 2003, ACFC/INF/OP/I(2004)002, para. 21; Opinion on Slovenia, 12 September, 2002, ACFC/INF/OP/I(2005)002, para. 17; Opinion on Spain, 27 November, 2003, ACFC/INF/OP/I(2004)004, para. 16; Opinion on Sweden, 25 August, 2002, ACFC/INF/ OP/I(2003)006, para. 15; Opinion on Switzerland, 20 February, 2003, ACFC/INF/OP/I(2003)007, para. 19; Opinion on the Former Yugoslav Republic of Macedonia, 27 May, 2004, ACFC/INF/OP/I(2005)001, para. 21; Opinion on Ukraine, 1 March, 2002, ACFC/INF/OP/I(2002)010, para. 15; Opinion on the United Kingdom, 30 November, 2001, ACFC/INF/OP/I(2002)006, para. 13.

77 Advisory Committee. Opinion on Germany, 1 March, 2006, ACFC/OP/II(2006)001, para. 25-26.

78 Hofmann, R. The Framework Convention for the Protection of National Minorities: An Introduction. In: Weller, M. A Commentary on the European Convention for the Protection of National Minorities. Oxford: Oxford University Press, 2005, p. 1-24. 
$<\ldots>$ confirms and takes up the individual human rights of ECHR, while in other respects it further develops and extends these rights to better suit the minority reality" 79 . The Framework Convention is a comprehensive document on the rights of persons belonging to national minorities. Although the Framework Convention is criticized because of its programme-type provisions that leave a wide margin of appreciation for contracting parties, the Advisory Committee, acting in the monitoring process under the Framework Convention, gives certain and concrete recommendations for contracting parties. The Advisory Committee presents individual opinions on contracting states. In those opinions, the Advisory Committee evaluates the implementation of the Framework Convention in a certain contracting state in a very broad manner, starting from the personal application of the Framework Convention ${ }^{80}$ and ending with clear recommendations how provisions of the programme-type nature have to be applied in situations, which differ from state to state ${ }^{81}$. This article does not seek to present and elaborate on the jurisprudence of the Advisory Committee, because the aim of this article focuses on the impact of general human rights on the protection for national minorities. Thus, the article presents only generally important information regarding the jurisprudence of the Advisory Committee in order to emphasize the uniqueness of the protection granted under specialized documents for national minorities in comparison with non-minorities treaties. In this context, it is important to underline that explanations

79 Henrard, K. Devising an Adequate System of Minority Protection. Individual Human Rights, Minority Rights and the Right to Self-Determination. Hague: Kluwer Law International, 2000, p. 213-214.

80 Advisory Committee: Opinion on Armenia, 12 May, 2002, ACFC/INF/OP/I(2003)001, para. 16; Opinion on Albania, 12 October, 2002, ACFC/INF/OP/I(2003)004, para. 19; Opinion on Azerbaijan, 22 May, 2003, ACFC/INF/OP/I(2004)001, para. 19; Opinion on Bosnia and Herzegovina, 27 May, 2004, ACFC/ INF/OP/I(2005)003, para. 22; Opinion on Bulgaria, 27 May, 2004, ACFC/INF/OP/I(2006)001, para. 15; Opinion on Croatia, 6 April, 2001, ACFC/INF/OP/I(2002)003, para. 16; Opinion on Cyprus, 6 April, 2001, ACFC/INF/OP/I(2002)004, para. 16; Opinion on Czech Republic, 6 April, 2001, ACFC/INF/ OP/I(2002)002, para. 15; Opinion on Denmark, 22 September, 2000, ACFC/INF/OP/I(2001)005, para. 15; Opinion on Finland, 22 September, 2000, ACFC/INF/OP/I(2001)002, para. 13; Opinion on Georgia, 19 March, 2009, ACFC/OP/I(2009)001, para. 24; Opinion on Hungary, 22 September, 2000, ACFC/ $\mathrm{INF} / \mathrm{OP} / \mathrm{I}(2001) 004$, para. 13; Opinion on Ireland, 22 May, 2003, ACFC/INF/OP/I(2004)003, para. 21; Opinion on Latvia, 3 October, 2008, ACFC/OP/I/(2008)002, para. 17; Opinion on Lithuania, 21 February, 2003, ACFC/INF/(OP/I(2003)008, para. 17; Opinion on Malta, 30 November, 2000, ACFC/ INF/OP/I(2001)006, para. 12; Opinion on Moldova, 1 March, 2002, ACFC/INF/OP/I(2003)002, para. 19; Opinion on Norway, 12 September, 2002, ACFC/INF/OP/OP/I(2003)003, para. 18; Opinion on Portugal, 6 October, 2006, ACFC/OP/I(2006)002, para. 16; Opinion on Russian Federation, 13 September, 2002, ACFC/INF/OP/I(2003)005, para. 19; Opinion on Serbia, 27 November, 2003, ACFC/INF/OP/I(2004)002, para. 21; Opinion on Slovenia, 12 September, 2002, ACFC/INF/OP/I(2005)002, para. 17; Opinion on Spain, 27 November, 2003, ACFC/INF/OP/I(2004)004, para. 16; Opinion on Sweden, 25 August, 2002, ACFC/INF/OP/I(2003)006, para. 15; Opinion on Switzerland, 20 February, 2003, ACFC/INF/ OP/I(2003)007, para. 19; Opinion on the Former Yugoslav Republic of Macedonia, 27 May, 2004, ACFC/ INF/OP/I(2005)001, para. 21; Opinion on Ukraine, 1 March, 2002, ACFC/INF/OP/I(2002)010, para. 15; Opinion on the United Kingdom, 30 November, 2001, ACFC/INF/OP/I(2002)006, para. 13.

81 Advisory Committee: Opinion on Bosnia and Herzegovina, 9 October, 2008, ACF/OP/II(2008)005, para. 163; Opinion on Czech Republic, 24 February, 2005, ACFC/INF/OP/II(2005)002, para. 126; Opinion on Montenegro, 28 February, 2008, ACFC/OP/I/(2008)001, para. 75; Opinion on Estonia, 1 April, 2011, ACFC/OP/III(2011)004, para. 112; Opinion on Poland, 20 March, 2009, ACFC/OP/II(2009)002, para. $144,145$. 
and interpretations given in the mentioned opinions of the Advisory Committee present the scope of certain provisions of the Framework Convention. Despite the fact that the activity of the Advisory Committee is criticized for its dependence and reliance on the Committee of Ministers (a political body), the Framework Convention, the Committee of Ministers, assisted by the Advisory Committee, create the only one mechanism in international law specifically dealing with the issues concerning the protection of persons belonging to national minorities and thus creating a unique system in this area. The activity of the Advisory Committee clarifies the content of the rights granted under the Framework Convention and the ambit of the obligations of contracting states.

The Framework Convention presents a different treatment: "in the Framework Convention, the differential rights are those set out in the text. McKean reminds us that special rights for minority groups are designed to produce an equilibrium between different situations, and should maintained as long as the groups concerned wish. Dimitrov suggests that absence from a legal system of differential rights means the absence of conditions for the maintenance of minority distinctiveness. Such a situation, he argues, leave no choice but to assimilate into majority, an assimilation (involuntary by definition), violating the prohibition of policies or practices aimed at assimilation of persons belonging to minorities against their will. Accordingly, the minority rights instrument turns a common argument on its head: that differential rights are the problem from a human rights perspective; on the contrary, the problem would be their absence" 82 .

International human rights law forms the general basis for the protection of persons belonging to national minorities. In order to protect the particularities of those persons, general human rights have to be supplemented by specialized provisions. In this context, it is important to underline the statement of Henrard, who notes that "a "full blow" system of minority protection consist of a conglomerate of rules and mechanisms enabling an effective integration of the relevant population groups, while allowing them to retain their separate characteristics. Such system is based on two pillars or basic principles, namely, the prohibition of discrimination on the one hand and measures designed to protect and promote the separate identity of the minority groups on the other hand" 83 . Apart from this, Henrard in her publication "The Ambiguous Relationship Between Religious Minorities and Fundamental (Minority) Rights" 84 states that "...fundamental rights in their current formulations and interpretations do not provide adequate protection for religious minorities" 85 . Also, Akermark stresses that "international law approaches minority rights primarily as rights of individuals and within the context

82 Thornberry, P. The Framewok Convention on National Minorities: A Provisional Appraisal and Memory of the Baltic States. Baltic Yearbook of International Law. 2002, 2: 127-157.

83 Henrard, K. Devising an Adequate System of Minority Protection. Individual Human Rights, Minority Rights and the Right to Self-Determination. Hague: Kluwer Law International, 2000, p. 10.

84 Henrard, K. The Ambiguous Relationship Between Religious Minorities and Fundamental (Minority) Rights. Hague: Eleven International Publishing, 2011.

85 Ibid., p. 85. 
of human rights" $"$. It may be concluded that general human rights alone do not offer effective protection for national minorities: general human rights have to be supported and supplemented by special mechanisms in order to ensure the effective preservation and promotion of the identity of a national minority.

\section{Conclusions}

General human rights in combination with the principles of non-discrimination and equality are essential for the purpose to ensure equal treatment of persons, including those belonging to national minorities. This creates only basic guarantees for the protection of persons belonging to national minorities without special purpose to preserve the particularities of a national minority. In this way, general human rights protect persons belonging to national minorities in a narrow sense without special clauses ensuring the preservation and promotion of the identity of a national minority. Consequently, the core international human rights treaties provide the protection for persons belonging to national minorities on the basis of individual human rights in a strict manner, which is limited to the scope of a certain general human right. Moreover, individual protection of human rights does not guarantee the protection for a national minority as a group of persons. General human rights per se do not establish rights of persons belonging to national minorities and thus constitute an indirect mechanism for the protection of those persons. Thus, general human rights alone do not offer effective protection for national minorities.

Accordingly, general human rights need to be supplemented by special provisions in order to ensure the effective protection for persons belonging to national minorities. Thus, the protection of persons belonging to national minorities have to be based on two pillars: 1) general human rights in conjunction with principles of non-discrimination and equality for the purpose of equal treatment and 2) specialized clauses devoted for the promotion and preservation of the identity of a national minority. Particularities that differ persons belonging to national minorities require ensuring the protection of double approach. The approach of the mentioned kind is represented by the interaction between documents, establishing general human rights (HRD, CCPR, CESCR, CERD), and specialized documents for the protection of national minorities (the Declaration, the Framework Convention). The protection of double approach guarantees the protection not only for individuals, but also for a national minority as a group of persons ensuring rights of collective nature. To conclude, the effective protection for national minorities is offered on the basis of general human rights that are supplemented with special provisions.

86 Athanasia Spiliotopoulou Akermark. Justifications of Minority Protection in International Law. Sweden: Iustus Publishing Company, 1997, p. 48. 


\section{References}

Advisory Committee: Opinion on Armenia, 12 May, 2002, ACFC/INF/OP/I(2003)001; Opinion on Albania, 12 October, 2002, ACFC/INF/OP/I(2003)004; Opinion on Azerbaijan, 22 May, 2003, ACFC/INF/ OP/I(2004)001; Opinion on Bosnia and Herzegovina, 27 May, 2004, ACFC/INF/ OP/I(2005)003; Opinion on Bulgaria, 27 May, 2004, ACFC/INF/OP/I(2006)001; Opinion on Croatia, 6 April, 2001, ACFC/ INF/OP/I(2002)003; Opinion on Cyprus, 6 April, 2001, ACFC/INF/OP/I(2002)004; Opinion on Czech Republic, 6 April, 2001, ACFC/INF/OP/I(2002)002; Opinion on Denmark, 22 September, 2000, ACFC/INF/OP/I(2001)005; Opinion on Finland, 22 September, 2000, ACFC/ INF/OP/I(2001)002; Opinion on Georgia, 19 March, 2009, ACFC/OP/I(2009)001; Opinion on Hungary, 22 September, 2000, ACFC/INF/OP/I(2001)004; Opinion on Ireland, 22 May, 2003, ACFC/INF/ OP/I(2004)003; Opinion on Latvia, 3 October, 2008, ACFC/OP/I/(2008)002; Opinion on Lithuania, 21 February, 2003, ACFC/INF/(OP/I(2003)008; Opinion on Malta, 30 November, 2000, ACFC/INF/ OP/I(2001)006; Opinion on Moldova, 1 March, 2002, ACFC/INF/OP/I(2003)002; Opinion on Norway, 12 September, 2002, $\quad$ ACFC/INF/OP/OP/I(2003)003; Opinion on Portugal, 6 October, 2006, ACFC/OP/I(2006)002; Opinion on Russian Federation, 13 September, 2002, $\quad$ ACFC/INF/OP/I(2003)005; Opinion on Serbia, 27 November, 2003, ACFC/INF/OP/I(2004)002; Opinion on Slovenia, 12 September, 2002, ACFC/ $\mathrm{INF} / \mathrm{OP} / \mathrm{I}(2005) 002$; Opinion on Spain, 27 November, 2003, ACFC/INF/ OP/I(2004)004; Opinion on Sweden, 25 August, 2002, ACFC/INF/OP/I(2003)006; Opinion on Switzerland, 20 February, 2003,
ACFC/INF/OP/I(2003)007; Opinion on the Former Yugoslav Republic of Macedonia, 27 May, 2004, ACFC/INF/OP/I(2005)001; Opinion on Ukraine, 1 March, 2002, ACFC/ INF/OP/I(2002)010; Opinion on the United Kingdom, 30 November, 2001, ACFC/ INF/OP/I(2002)006; Advisory Committee: Opinion on Armenia, 12 May, 2002, ACFC/ INF/OP/I(2003)001; Opinion on Albania, 12 October, 2002, ACFC/INF/OP/I(2003)004; Opinion on Azerbaijan, 22 May, 2003, ACFC/INF/OP/I(2004); Opinion on Bosnia and Herzegovina, 27 May, 2004, ACFC/ INF/OP/I(2005)003; Opinion on Bulgaria, 27 May, 2004, ACFC/INF/OP/I(2006)001; Opinion on Croatia, 6 April, 2001, ACFC/ INF/OP/I(2002)003; Opinion on Cyprus, 6 April, 2001, ACFC/INF/OP/I(2002)004; Opinion on Czech Republic, 6 April, 2001, ACFC/INF/OP/I(2002)002; Opinion on Denmark, 22 September, 2000, ACFC/INF/OP/I(2001)005; Opinion on Finland, 22 September, 2000, ACFC/ INF/OP/I(2001)002; Opinion on Georgia, 19 March, 2009, ACFC/OP/I(2009)001; Opinion on Hungary, 22 September, 2000, ACFC/INF/OP/I(2001)004; Opinion on Ireland, 22 May, 2003, ACFC/INF/ OP/I(2004)003; Opinion on Latvia, 3 October, 2008, ACFC/OP/I/(2008)002; Opinion on Lithuania, 21 February, 2003, ACFC/INF/(OP/I(2003)008; Opinion on Malta, 30 November, 2000, ACFC/INF/ OP/I(2001)006; Opinion on Moldova, 1 March, 2002, ACFC/INF/OP/I(2003)002; Opinion on Norway, 12 September, 2002, ACFC/INF/OP/OP/I(2003)003; Opinion on Portugal, 6 October, 2006, ACFC/OP/I(2006)002; Opinion on Russian Federation, 13 September, 2002, ACFC/INF/OP/I(2003)005; Opinion on Serbia, 27 November, 2003, ACFC/INF/OP/I(2004)002; Opinion on 
Slovenia, 12 September, 2002, ACFC/ INF/OP/I(2005)002; Opinion on Spain, 27 November, 2003, ACFC/INF/ OP/I(2004)004; Opinion on Sweden, 25 August, 2002, ACFC/INF/OP/I(2003)006; Opinion on Switzerland, 20 February, 2003, ACFC/INF/OP/I(2003)007; Opinion on the Former Yugoslav Republic of Macedonia, 27 May, 2004, ACFC/INF/OP/I(2005)001; Opinion on Ukraine, 1 March, 2002, ACFC/ INF/OP/I(2002)010; Opinion on the United Kingdom, 30 November, 2001, ACFC/INF/ OP/I(2002)006.

Airey v. Ireland, No. 6289/739, October 1979, Series A No. 32.

Akermark, A. S. Justifications of Minority Protection in International Law. Sweden: Iustus Publishing Company, 1997.

Alfredson, G. Minority Rights: A Summary of Existing Practice. In: Philips, A.; Rosas, A. (eds.). Universal Minority Rights. Turku/ Åbo and London: Åbo Akademi University Institute for Human Rights Minority Group (International), 1995, p. 77-87.

Ballantyne, Davidson and McIntyre v. Canada, No. 359/1989, 385/1989, 31 March, 1993.

Baczkowski and Others v. Poland, No. 1543/06, 3 May, 2007.

Bloed, A. Monitoring the Human Dimension of the OSCE. In: Alfredson, G.; Grimheden, J.; Ramcharan, B. G.; de Zayas, A. (eds.). International Human Rights Monitoring Mechanisms. Essays in Honour of Jakob Th. Moller. Hague: Kluwer Law International, 2001.

Burghartz v. Switzerland, 22 February, 1994, Series A No. 280 B.

Burghartz v. Switzerland, No. 16213/90, 22 February, 1994, Series A No. 280-B.

Capotorti, F. Study on the Rights of Persons Belonging to Ethnic, Religious and Linguistic Minorities. New York: United Nations, 1991, p. 18.

Case "Relating to Certain Aspects of the Laws on the Use of Languages in Education in Belgium” v. Belgium (merits), No. 1474/62, 23 July, 1968, Series A No. 6.
Concluding Document of the Madrid Meeting of 1983, Concluding Document of the Vienna Meeting of 1989.

Convention for the Protection of Human Rights and Fundamental Freedoms. CETS No.: 005 .

Declaration on the Rights of Persons Belonging to National or Ethnic, Religious and Linguistic Minorities. Distr. GENERAL, 18 December, 1992.

Diergaardt et al. v. Namibia, No. 760/1997, UN Doc. CCPR/C/69/D/760/1997; Coeriel and UArik v. Netherlands, No. 453/1991, UN Doc. CCPR/C/52/D/453/1991.

European Charter for Regional or Minority Languages. CETS No.: 148.

European Commission for Democracy through Law. Report on Non-citizens and Minority Rights. Venice, 15-16 December, 2006. Council of Europe, No. CDLAD(2007)001 Or. Engl.

Explanatory Report of European Charter for Regional or Minority Languages, ETS No. 148.

Explanatory Report of the Framework Convention for the Protection of National Minorities, ETS No. 157.

Framework Convention for the Protection of National Minorities. CETS No.: 157.

Girasoli, N. National Minorities: Who Are They? Budapest: Akademia Kiado, 1995.

Gorzelick and Others v. Poland, [GC], No. 44158/98, 17 February, 2004, ECHR 2004-I.

Guillot v. France, 24 October, 1996, Reports 1996 V, p. 1602-1603, section 21.

Güzel Erdagöz v. Turkey, No. 37483/02, 21 October, 2008.

Helsinki Final Act. [interactive]. [accessed on 12-09-2013]. <http://www.osce.org/ $\mathrm{mc} / 39501$ ? download $=$ true $>$.

Henrard, K. Devising an Adequate System of Minority Protection. Individual Human Rights, Minority Rights and the Right to Self-Determination. Hague: Kluwer Law International, 2000.

Henrard, K. The Impact of International Nondiscrimination Norms in Combination with 
General Human Rights for the Protection of National Minorities: Several United Nations Human Rights Conventions. Strasbourg: Committee of Experts on Issues Relating to the Protection of National Minorities, DHMIN(2006)021, 24 October, 2006.

Henrard, K. The Ambiguous Relationship Between Religious Minorities and Fundamental (Minority) Rights. Hague: Eleven International Publishing, 2011.

Hofmann, R. The Framework Convention for the Protection of National Minorities: An Introduction. In: Weller, M. A Commentary on the European Convention for the Protection of National Minorities. Oxford: Oxford University Press, 2005.

Human Rights Committee. General Comment No. 18 "Non-discrimination". U.N. Doc. HRI/GEN/1/Rev.1 at 26 (1994), 4 October, 1990.

Human Rights Committee. General Comment No. 23: The Rights of Minorities (Art. 27). 8 April, 1994, CCPR/C/21/Rev.1/Add.5.

Informationsverein Lentia and Others $v$. Austria, 24 November, 1993, Application No. 13914/88; 15041/89; 15717/89; 15779/89; 17207/90.

International Convention on the Elimination of All Forms of Racial Discrimination. United Nations. Treaty Series. 1966, (660): 195.

International Covenant on Civil and Political Rights. United Nations. Treaty Series. 1966, (999): 171, and (1057): 407.

International Covenant on Economic, Social and Cultural Rights. United Nations. Treaty Series. 1966, (993): 3.

Ivan Kitok v. Sweden, No. 197/1985, 27 July, 1988, U.N. Doc. CCPR/C/33/D/197/1985.

Kemal Tažkżn and Others v. Turkey, No. 30206/04, 37038/04, 43681/04, 45376/04.

Kovaševič, D. International Minority Protection System. [interactive]. [accessed on 14-10-2010]. <http://www.kas.de/ upload/auslandshomepages/serbien/ Kovacevic_en.pdf $>$.

Mentzen v. Latvia (dec.), No. 71074/01, 7 December, 2004, ECHR 2004-XII.
Pantassuglia, G. Minority Issues Handbook. Minorities in International Law. Strasbourg: European Centre for Minority Issues, Council of Europe Publishing, 2007.

Parliamentary Assembly. Recommendation No. 1134 (1990), Recommendation No. 1201 (1993), Recommendation No. 1492 (2001).

Permanent Court of International Justice. Advisory Opinion of 6 April, 1935. Minority Schools in Albania. Series A./B., No. 64.

Protocol No. 12 to the Convention for the Protection of Human Rights and Fundamental Freedoms. CETS No.: 177.

Račkauskaitè-Burneikienè, A. Summary of the Doctoral Dissertation "Linguistic Guarantees for Persons Belonging to National Minorities". Social Sciences, Law (01 S). Vilnius: Mykolas Romeris University, 2012, p. 259.

Račkauskaitė-Burneikienè, A. Tautinèms mažumoms priklausančiu asmenu kalbinès garantijos: tarptautiniu standartu igyvendinimas Lietuvos Respublikoje. Daktaro disertacija. Socialiniai mokslai, teisè. Vilnius: Mykolo Romerio Universitetas, 2012, p. 33.

Report submitted by Armenia pursuant to Article 25, paragraph 1 of the Framework Convention for the Protection of National Minorities, 11 June, 2001, ACFC/ SR(2001)004.

Report submitted by Hungary pursuant to Article 25, paragraph 1 of the Framework Convention for the Protection of National Minorities, 21 May, 1999, ACFC/SR/ (1999)010.

Report submitted by Slovakia pursuant to Article 25, paragraph 1 of the Framework Convention for the Protection of National Minorities, 4 May, 1999, ACFC/ SR(1999)008.

Sandra Lovelace v. Canada, No. 24/1977, 30 July, 1981, U.N. Doc. Supp. No. 40 (A/36/40).

Stjerna v. Finland, No. 18131/91, 25 November, 1994, Series A No. 299-B.

Šiškina and Šiškins v. Latvia (dec.), No. 59727/00, 8 November, 2001. 
The Committee on the Elimination of Racial Discrimination. General Recommendation No. 32 "The Meaning and Scope of Special Measures in the International Convention on the Elimination of All Forms Racial Discrimination". Distr. GENERAL CERD/C/GC/32, 24 September, 2009.

Thornberry, P. The Framework Convention on National Minorities: A Provisional Appraisal and Memory of the Baltic States. Baltic Yearbook of International Law. 2002, 2: 127-157.

Tulkens, F. The Protection of National Minorities in the Case-Law of the European Court of Human Rights. Strasbourg: Committee of Experts on Issues Relating to the Protection of National Minorities (DHMIN), 7th Meeting, 12-13 March, 2008, p. 2. United Nation, Human Rights, Charter Based and Treaty Based Bodies, Core International Human Rights Treaties, International Human Rights Law. [interactive]. [accessed on 09-08-2013]. <http://www. ohchr.org/EN/ProfessionalInterest/Pages/ InternationalLaw.aspx>.

Universal Declaration of Human Rights. Adopted by United Nation General Assembly Resolution 217 A (III) of 10 December, 1948.

Weller, M. The Rights of Minorities. A Commentary on the European Convention for the Protection of National Minorities. Oxford: Oxford University Press, 2005.

\section{BENDRŲJŲ ŽMOGAUS TEISIŲ İTAKA ASMENŲ, PRIKLAUSANČIŲ TAUTINĖMS MAŽUMOMS, APSAUGAI}

\section{Aistė Račkauskaitė-Burneikienė}

Mykolo Romerio universitetas, Lietuva

Santrauka. Tautinèms mažumoms priklausančiu asmenu apsauga yra sudetine tarptautinés žmogaus teisiu apsangos sistemos dalis. Tarptautine žmogaus teisiu apsanga yra konstruojama dviem pagrindais: bendruju žmogaus teisiu garantijomis bei specialiu teisiu užtikrinimu. Specialios teisès yra garantuojamos asmenims, priklausantiems potencialiai pažeidžiamoms asmenu grupems (vaiku teises, moteru teises, tautinems mažumoms priklausančiu asmenu teisès). Iškyla klausimas, kokia apimtimi bendrosios žmogaus teisès diskriminavimo ir lygybès principu pagrindu gali saugoti ir ginti tautinems mažumoms priklausančius asmenis. Taigi šiuo straipsniu yra siekiama nustatyti ir įvertinti, ar bendruju žmogaus teisiu pagrindu teikiama apsauga yra pakankama tautines mažumos tapatybès išsaugojimui.

Siekiant nustatyti tarptautinès teisés pagrindus, kurie saugo tautinems mažumoms priklausančius asmenims, pirmiausiai yra nagrinejami diskriminavimo draudimo bei lygybès principai kaip teisinès prielaidos ginti tautinèms mažumoms priklausančius asmenis bendruju žmogaus teisiu kontekste. Toliau nagrinejamos teises normos, nors ivirtintos bendrąsias žmogaus teises garantuojančiose tarptautinese sutartyse, tačiau specializuotai skirtos tautinems mažumoms priklausančiu asmenu apsaugai. Atliktas tyrimas rodo, kad tautinems mažumoms priklausančiu asmenu teisiu apsauga patenka į bendruju žmogaus teisiu apimti ir tampa tokios teises aspektu. Vis delto atkreiptinas demesys $\dot{z}$ tai, kad bendrosios žmogaus teises nerra tiesiogiai skirtos tautinems mažumoms priklausančiu asmenu ypatybiu apsaugai. 
Paskutineje straipsnio dalyje nagrinejami specializuoti tautinèms mažumoms priklausančiu asmenu apsaugos dokumentai. Apibendrinant atlikta tyrima yra daroma išvada, kad bendrosios žmogaus teisès per se nesaugo tautinèms mažumoms priklausančiu asmenu, todèl siekiant efektyviai užtikrinti šiu asmenu teises, sistema turi büti grindžiama dviem ramsčiais diskriminavimo draudimu, kuris garantuoja vienoda naudojimąsi bendrosiomis žmogaus teisemis, taip pat ir asmenims, priklausantiems tautinems mažumoms, bei specialiuju teisiu užtikrinimu, kurios puoseleja bei saugo tautinès mažumos tapatybę.

Reikšminiai žodžiai: tarptautine žmogaus teisiu apsauga, tautinès mažumos, diskriminavimo draudimas, lygybe, teises, garantuojamos tautinems mažumoms priklausantiems asmenims, Tarptautinis pilietiniu ir politinin teisiu paktas, Žmogaus teisiu ir pagrindinin laisviu apsaugos konvencija, Tautiniu mažumu apsaugos pagrindų konvencija.

Aistė Račkauskaitė-Burneikienė, Mykolo Romerio universiteto Teisės fakulteto Tarptautinès ir Europos Sajungos teisès instituto lektorè, socialinių mokslų (teisès krypties) daktarè. Mokslinių tyrimų kryptys: tarptautinè ir nacionalinė žmogaus teisių apsauga, tautinėms mažumoms priklausančių asmenų apsauga.

Aistė Račkauskaitė-Burneikienė, Mykolas Romeris University, Faculty of Law, Institute of International and European Union Law, Doctor of Social Sciences (Law), Lecturer. Research interests: international and national protection of human rights, the protection of persons belonging to national minorities. 